\title{
The Potential Role of Cinnamon in Human Health
}

\author{
Natalia Błaszczyk ${ }^{1} \mathbb{D}$, Angelina Rosiak ${ }^{1,2}$ (D) and Joanna Kałużna-Czaplińska 1,2,*(D) \\ 1 Institute of General and Ecological Chemistry, Faculty of Chemistry, Lodz University of Technology, \\ Zeromskiego 116, 90-924 Lodz, Poland; nat.bla95@gmail.com (N.B.); angelina.rosiak@p.lodz.pl (A.R.) \\ 2 CONEM Poland Chemistry and Nutrition Research Group, Faculty of Chemistry, Institute of General and \\ Ecological Chemistry, Lodz University of Technology, Zeromskiego 116, 90-924 Lodz, Poland \\ * Correspondence: joanna.kaluzna-czaplinska@p.lodz.pl
}

Citation: Błaszczyk, N.; Rosiak, A.; Kałużna-Czaplińska, J. The Potential Role of Cinnamon in Human Health. Forests 2021, 12, 648. https://doi.org/ $10.3390 /$ f12050648

Academic Editor: Apostolos

P. Kyriazopoulos

Received: 1 April 2021

Accepted: 18 May 2021

Published: 20 May 2021

Publisher's Note: MDPI stays neutral with regard to jurisdictional claims in published maps and institutional affiliations.

Copyright: (C) 2021 by the authors. Licensee MDPI, Basel, Switzerland. This article is an open access article distributed under the terms and conditions of the Creative Commons Attribution (CC BY) license (https:/ / creativecommons.org/licenses/by/ $4.0 /)$.

\begin{abstract}
Cinnamon is an unusual tropical plant belonging to the Lauraceae family. It has been used for hundreds of years as a flavor additive, but it has also been used in natural Eastern medicine. Cinnamon extracts are vital oils that contain biologically active compounds, such as cinnamon aldehyde, cinnamic alcohol, cinnamic acid, and cinnamate. It has antioxidant, anti-inflammatory, and antibacterial properties and is used to treat diseases such as diabetes and cardiovascular disease. In folk medicine, cinnamon species have been used as medicine for respiratory and digestive disorders. Their potential for prophylactic and therapeutic use in Parkinson's and Alzheimer's disease has also been discovered. This review summarizes the available isolation methods and analytical techniques used to identify biologically active compounds present in cinnamon bark and leaves and the influence of these compounds in the treatment of disorders.
\end{abstract}

Keywords: cinnamon; bioactive compounds; cinnamon aldehyde; separation methods; analytical techniques

\section{Introduction}

Cinnamon (Cinnamomum zeylanicum) is a spice mainly obtained from cinnamon bark and leaves. It is an evergreen tree belonging to the Lauraceae family. The most recognizable species are Cinnamomum cassia (L.) J. Presl, Cinnamomum camphora, and Cinnamomum zeylanicum. This plant has been known in several cultures for centuries, mostly in culinary applications. Cinnamon is popular for its aroma. It is incorporated in the aroma composition of perfumes [1]. Composites of this spice are used in the industry. Supplementation with cinnamon essential oil extracts in poultry diets has effects on immunity and microbiological aspects [2]. Cinnamon oils have also been found in the development of new active packaging films based on whey protein containing chitosan nanofibers. The results of Fourier-transform infrared spectroscopy (FTIR) and scanning electron microscopy (SEM) tests show a homogeneous distribution of chitosan nanofibers in the film and the effect of chitosan nanofibers on mechanical properties and water vapor permeability [3].

Cinnamon is composed of many compounds with a biologically active formula on which its properties depend. Extracts taken from various parts of the plant differ significantly in chemical composition (Figure 1). This means that they have different properties. Volatile oils extracted from the leaves, bark, and root bark of the cinnamon plant contain the same spectrum of monoterpene hydrocarbons. However, they differ in their main compounds. Cinnamon aldehyde is the basic compound found in the cinnamon bark. The leaf oil contains mainly eugenol, whereas in the root bark oil the primary compound is camphor [4]. 


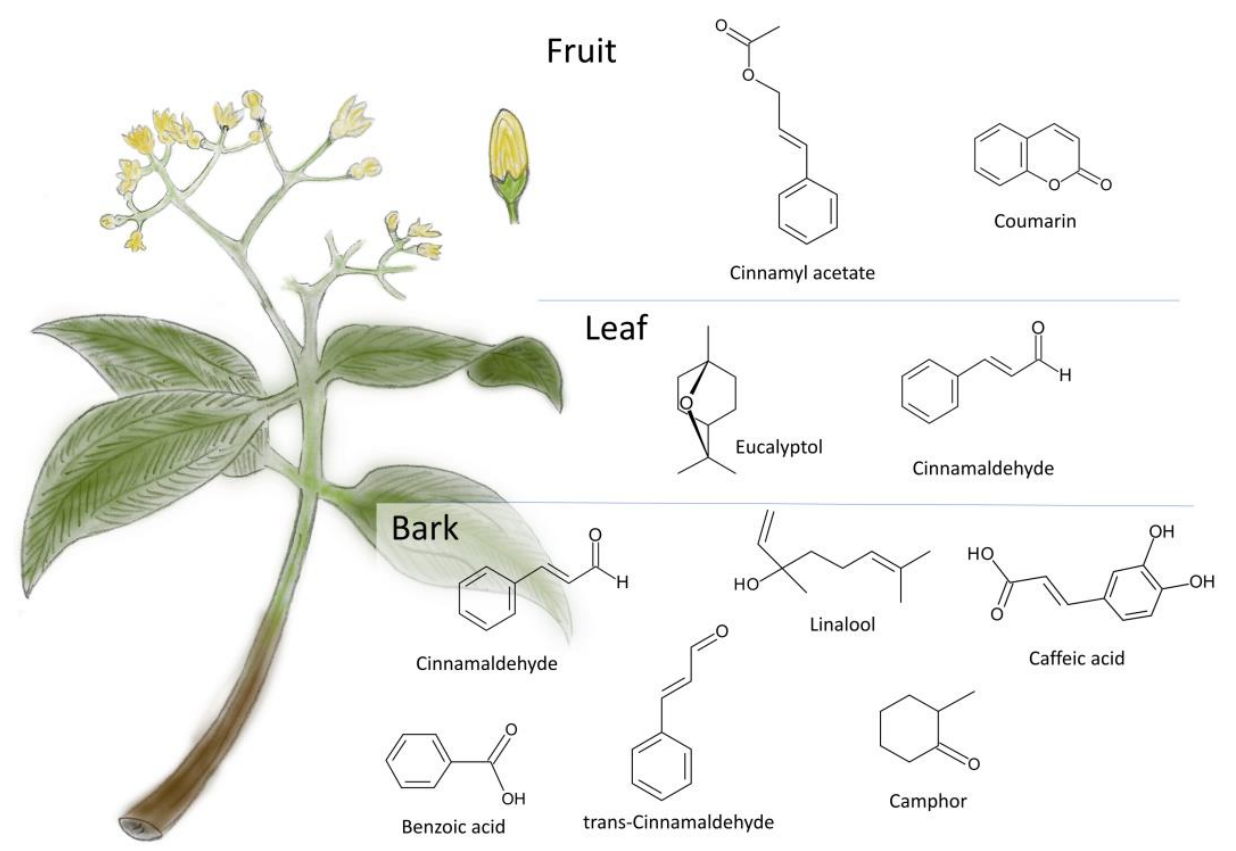

Figure 1. Selected bioactive compounds of cinnamon in different parts of the plant $[5,6]$.

Biologically active compounds constitute a large group. These compounds can be divided into two groups according to their positive and negative impacts on human and animal organisms. Both of these groups are of particular interest today because of their novel properties. Biologically active compounds of cinnamon are interesting from the point of view of human health [4].

Cinnamon is an attractive spice because of its taste, but it may also be of pharmaceutical interest [7]. Secondary metabolites constitute a large proportion of synthetic compounds with health-promoting effects. Most of them are dietetically neutral, but they usually have a positive effect on human health. Plant oils are considered to be one of the safer compounds used in medicine. They are used in a wide range of food recipes as natural antioxidants [7]. The pharmacological properties come from polyphenolic constituents, including phenolic acids coumarin and proanthocyanidin, as well as volatile essential oils.

Cinnamon has many different health properties that have been reported, such as its antioxidant content and its effect on diabetes and neurological, microbial, and cardiovascular diseases due to the properties of bioactive components [4]. Cinnamaldehyde is reported as a factor that decreases the production and expression of nitric oxide (NO), interleukin (IL)-1b, IL-6, and tumor necrosis factor (TNF)-a in lipopolysaccharide (LPS)-activated BV2 microglia and is therefore anti-neuroinflammatory [8]. Moreover, it has been reported to aid in neuroprotection due to its potential in inhibiting tau protein aggregation, the hallmark of Alzheimer's disease (AD) [8]. Cinnamaldehyde and eugenol are responsible for protecting the gut from injury from conditions of inflammation, infections, and oxidative stress. Cinnamaldehyde also has the potential to control harmful fungus and mycotoxin contamination of agricultural commodities [9].

Other main bioactive compounds of cinnamon are procyanidin polymer type A, cinnamic acid, and coumarin. The presence and amount of the constituents depend on the method of separation, extraction, and purification. Single-phase extraction is a direct process of oil production [10].

The concentration of cinnamon compounds also depends on the species of plant, the tree section, and the stage of maturity. These factors may affect the key properties of the cinnamon extract. For example, Cinnamomum cassia (L.) J. Presl has a higher coumarin content. The content of the ingredients also varies depending on the section of the tree. The upper and middle segments of the cinnamon bark are more effective for extracting cinnamon oil, and the mature tree has the highest yield value of cinnamon trans-aldehyde. 
However, the efficiency of the compounds in the extracted cinnamon oil depends on the separation methods, solvents, and all the parameters related to the extraction/separation process, such as time, temperature, and pressure. Optimization of the extraction process is an important factor that influences the composition of the oil [11-13]. The various methods are used to separate the compounds from cinnamon. Traditional methods of extracting essential oils are organic solvent extraction, hydrodistillation, and steam distillation. The most common ones are those that use solvents, such as methanol, ethanol, and chloroform [11]. Recently, novel extraction methods using supercritical fluid, assisted by microwaves or ultrasounds, have been developed [14]. Supercritical carbon dioxide extraction is also used. Gas chromatography-mass spectrometry (GC-MS) analysis shows that the main components of the extract obtained by this method are cinnamic aldehyde, $\beta$-caryophyllene, longifolene, and $\beta$-amyrin [15]. However, the safest and most accessible method for human health is water extraction. The profiling of aqueous cinnamon extract with the use of ultraperformance liquid chromatography-high-resolution mass spectrometry (UPLC-HRMS) confirmed the presence of compounds such as camphor, L(-)-carnitine, and rosavin, which are characterized by biologically active properties [16].

The quantities are measured according to different analytical chemical methods, such as high-performance liquid chromatography (HPLC), liquid chromatography-mass spectrometry (LC-MS), gas chromatography-mass spectrometry (GC-MS), and gas chromatography coupled with flame ionization detection (GC-FID) [17]. Using more advanced compound analysis techniques, scientists can better characterize and study the composition of the cinnamon oil. The use of gas chromatography with time-of-flight mass spectrometry (GCxGC-TOFMS) resulted in the identification of as many as 80 compounds, while the use of GC-MS showed the presence of only 7 compounds in the analyzed samples. The compounds identified by GCxGC-TOFMS are 8 ketones, 7 monoterpene hydrocarbons, 30 oxidized monoterpenes, 4 sesquiterpene hydrocarbons, and 23 oxidized sesquiterpene hydrocarbons. Nowadays, GCxGC-TOFMS is known as the most accurate technique for the separation and characterization of essential oil components, especially for complex samples [18].

Research on cinnamon and its properties provides an opportunity to advance the field of natural medicine. Cinnamon contains numerous bioactive compounds that have pharmacological properties. The awareness of scientists and laypeople regarding its use is important. It can be a cheap and widely available alternative to expensive synthetic, and often ineffective, medicines. Cinnamon research is a return to natural medicine that was once popular and effective. The development of analysis techniques allows for a deeper understanding of Eastern medicine and a rediscovery of the health benefits of plant products.

The aim of this review was to summarize the current state of knowledge about active compounds in cinnamon, their biological properties, and the potential role of cinnamon in human health. Attention was also paid to the potential contribution of some biological compounds of cinnamon to the diet of people with different diseases or metabolic disorders. Finally, we analyzed the current analytical techniques that are used to determine biological compounds in cinnamon. Methods of separation and methods of analysis of biological compounds have changed over the years. The review aims to present the latest developments in the field of science. The development of natural medicine and the demonstration of the properties of the earth's natural resources are groundbreaking, because by using the latest technology, we can deepen the subject of natural treating.

Nowadays, it is critical to find a sustainable source of natural remedies, and cinnamon bark is one such example. Further research will be needed to validate the health benefits in the diseases discussed in part 3 of this review.

\section{Methods}

The below review was conducted using widely available literature about medicinal plant between 2010 and 2021. The searches were performed using databases, in- 
cluding PubMed (http:/ / www.ncbi.nlm.nih.gov / pubmed (accessed on 22 March 2021), ScienceDirect (http://www.sciencedirect.com (accessed on 22 March 2021), Scopus ( http:/ / www.scopus.com (accessed on 22 March 2021)), and Google Scholar (http:/ / www. scholar.google.com (accessed on 22 March 2021) For the literature review, we focused on the most recent publications and keywords: "cinnamon extract", "biologically active compounds", "cinnamaldehyde", "medicinal properties of cinnamon", "cinnamon used in medicine", and "natural plants in medicine".

Our review is split into two parts. The first part is focused on examples of sample preparation and chromatographic methods used in the analysis of cinnamon extract. The second part consists of a summary on compound properties that naturally occur in cinnamon, which can be determined by chromatographic methods. It also includes cinnamon applications in various medicinal fields.

\section{Results and Discussion}

\subsection{Bioactive Compounds Determined in Cinnamon \\ Determination Methods for Compounds Naturally Occurring in Cinnamon}

Cinnamon is a plant rich in various bioactive compounds. Table 1 shows selected examples of compounds determined in different parts of this plant.

The most common method used to prepare cinnamon extract (oils) is hydrodistillation, a steam distillation in a Clevenger-type apparatus [18-25]. Small fragments of bark, leaves, or fruits are subjected to extraction. The process takes several hours and leads to receipt of an oil rich in bioactive substances. Extraction of oils from leaves [10] and bark [13] can also be carried out using maceration extraction. For bark extraction, it is also possible to use a wide range of other extraction techniques, including distillation [26], steam distillation [27], supercritical $\mathrm{CO}_{2}$ extraction [28], subcritical extraction [12,29], extraction in Soxhlet apparatus [27], water extraction [16,30], and extraction in Soxhlet apparatus. Chromatographic analysis of the obtained extract is usually carried out with the use of gas chromatography techniques, mainly GC-MS [10,19-22,24-26,29-31], but also GC [22,28], GC-FID [19,20,23], or GCxGC-TOFMS [18]. Additionally, liquid chromatography is used for the analysis of cinnamon extracts, including HPLC [12,27], reversed-phase high-performance liquid chromatography (RP-HPLC) [13], liquid chromatography with tandem mass spectrometry (LC-MS/MS) [32], and ultraperformance liquid chromatography-high-resolution mass spectrometry (UPLC-HRMS) [33]. Other examples of methods used in extract analyses are the Folin-Ciocalteu colorimetric method $[13,34]$ and direct analysis in real-time mass spectrometry (DART-MS) [35].

All the discussed analysis methods allow the determination of a number of biologically active compounds. As previously mentioned, these are mainly cinnamaldehyde [12,24-31,35], but also eugenol [10,19-21,23,26,28], linalool [19,21-23], and phenols [34], among others.

The knowledge of the composition of cinnamon extract obtained by different methods allows for determining which components are responsible for the health-promoting properties of cinnamon. Comparison of extracts from different parts of the plant can serve as a basis for selecting the richest source of bioactive compounds. 
Table 1. Selected separation methods and analysis techniques of the determination of compounds in cinnamon samples.

\begin{tabular}{|c|c|c|c|c|c|}
\hline Part & Separation Technique & Sample Preparation & Analysis Method & Determined Compounds* & Ref. \\
\hline \multirow{4}{*}{ Leaf } & Hydrodistillation & Using a Clevenger-type apparatus. & GCxGC-TOFMS & $\begin{array}{l}\text { 4-Hydroxy-4-methyl-2-pentanone, } \\
\text { nopinone, p-mentha-1,5-dien- } 8 \text {-ol, } \\
\text { verbenone, methyl eugenol, } \\
\text { spathulenol, mustakone }\end{array}$ & Silva et al. [18] \\
\hline & Hydrodistillation & $\begin{array}{l}\text { Ground cinnamon and submitted } \\
\text { to hydrodistillation using a } \\
\text { Clevenger-type apparatus. }\end{array}$ & $\begin{array}{l}\text { GC-MS } \\
\text { GC-FID }\end{array}$ & $\begin{array}{l}\alpha \text {-thujene, camphene, sabinene, } \\
\text { p-cymene, trans-linalool oxide } \\
\text { (furanoid), linalool, borneol, } \\
\alpha \text {-terpineol, (E)-cinnamaldehyde, } \\
\text { eugenol, (E)-caryophyllene, } \\
\text { (E)-cinnamyl acetate, } \alpha \text {-humulene, } \\
\text { ar-curcumene, } \gamma \text {-gurjunene, } \\
\text { caryolan-8-ol, camphor, limonen }\end{array}$ & $\begin{array}{c}\text { Farias et al. [19]; } \\
\text { Pragadheesh et al. [20] }\end{array}$ \\
\hline & $\begin{array}{l}\text { Hydrodistillation, supercritical } \\
\text { extraction techniques }\end{array}$ & $\begin{array}{l}\text { Small pieces of samples were } \\
\text { immersed in distilled water. }\end{array}$ & GC-MS & Linalool, eugenol & $\begin{array}{c}\text { Farias et al. [19]; } \\
\text { Jayaprakasha \& Jagan } \\
\text { Mohan Rao [21] }\end{array}$ \\
\hline & Maceration extraction & $\begin{array}{l}\text { Crushed cinnamon samples } \\
\text { were placed in ethanol. }\end{array}$ & GC-MS & $\begin{array}{l}\text { Eugenol, trans-caryophyllene, } \\
\text { 1,4,8-cycloundecatriene, glycerol } \\
\text { triacetate, 4,6-dimethyldodecane, } \\
\text { benzyl benzoate, trans-2-tridecenal, } \\
\text { tetradecanamide, oleic acid amide }\end{array}$ & Khasanah et al. [10] \\
\hline Fruit & Hydrodistillation & $\begin{array}{c}\text { Ground cinnamon and submitted to } \\
\text { hydrodistillation using a } \\
\text { Clevenger-type apparatus. }\end{array}$ & $\begin{array}{c}\mathrm{GC} \\
\mathrm{GC}-\mathrm{MS}\end{array}$ & Linalool & Kaul et al. [22] \\
\hline Bark & Hydrodistillation & $\begin{array}{c}\text { Small pieces of cinnamon bark were } \\
\text { immersed in distilled water and extracted } \\
\text { using a Clevenger-type apparatus. }\end{array}$ & GC-FID & $\begin{array}{c}\text { Linalool, eugenol, } \alpha \text {-pinene, } \\
\text { sabinene, } \alpha \text {-terpinene, limonene, } \\
\text { 1,8-cineole, } \alpha \text {-terpinene, terpinolene, } \\
\text { terpinen- } 4 \text {-ol, terpineol, methyl } \\
\text { eugenol, } \alpha \text {-selinene }\end{array}$ & Abdelwahab et al. [23] \\
\hline
\end{tabular}


Table 1. Cont.

\begin{tabular}{|c|c|c|c|c|c|}
\hline Part & Separation Technique & Sample Preparation & Analysis Method & Determined Compounds * & Ref. \\
\hline & Hydrodistillation & $\begin{array}{l}\text { Small pieces of cinnamon bark were } \\
\text { immersed in distilled water. }\end{array}$ & GC-MS & $\begin{array}{l}\text { Cinnamaldehyde, trans-cinnamyl } \\
\text { acetate, coumarin acid, } \\
\text { 9-octadecenoic acid, } \\
\text { 1,4-benzenedicarboxylic acid, } \\
\alpha \text {-pinene, 1,8-cineole, } \\
\text { benzaldehyde, } \gamma \text {-terpinene, linalool, } \\
\text { camphenilol, borneol, cyclohexane, } \\
\alpha \text {-terpinene, eugenol, hydrocinnamic } \\
\text { acid, } \delta \text {-cadinene, propenoic acid, } \\
\text { caryophyllene oxide, naphthalenol, } \\
\text { hexadecanoic acid, phthalic acid }\end{array}$ & Kallel et al. [24] \\
\hline & Hydrodistillation & $\begin{array}{l}\text { Small pieces of samples were immersed } \\
\text { in distilled water. }\end{array}$ & GC-MS & $\begin{array}{c}\alpha \text {-pinene, camphene, } \beta \text {-pinene, } \\
\text { p-cymene, limonene, } 1,8 \text {-cineole, } \\
\text { linalool, borneol, } 4 \text {-terpineol, } \\
\beta \text {-terpineol, bornyl acetate, } \\
\alpha \text {-copaene, } \beta \text {-elemene, zingiberene, } \\
\text { trans- } \beta \text {-caryophyllene, } \alpha \text {-humulene, } \\
\gamma \text {-muurolene, } \alpha \text {-guaiene, } \\
\alpha \text {-muurolene, } \delta \text {-cadinene, } \\
\text { cadina- } 1,4 \text {-diene, } \alpha \text {-calacorene, } \\
\alpha \text {-cubebene, } \delta \text {-cadinol, } \\
\text { benzaldehyde, benzylacetaldehyde, } \\
\text { cinnamaldehyde, cinnamyl acetate, } \\
\text { coumarin }\end{array}$ & Muhammad et al. [25] \\
\hline & Distillation & $\begin{array}{l}\text { Dry ground samples of cinnamon were } \\
\text { mixed with distilled water in bottom flask. }\end{array}$ & GC-MS & $\begin{array}{l}\text { Eucalyptol, benzene propanol, } \\
\text { trans-cinnamaldehyde, cinnamyl } \\
\text { acetate, } \alpha \text {-muurolene, coumarin } \\
\text { (2H-1-benzopyran-2-one), linalool, } \\
\text { eugenol, caryophyllene, eugenyl } \\
\text { acetate, benzyl benzoate }\end{array}$ & Gotmare \& Tambe [26] \\
\hline & Steam distillation method & $\begin{array}{l}\text { Cinnamon sticks were mashed in smaller } \\
\text { pieces and placed in the distillation flask. }\end{array}$ & HPLC & Cinnamaldehyde & Wong et al. [27] \\
\hline & Supercritical $\mathrm{CO}_{2}$ extraction & $\begin{array}{l}\text { Crushed cinnamon was placed in } \\
\text { an apparatus. }\end{array}$ & GC & Cinnamaldehyde, eugenol & $\begin{array}{l}\text { Masghati \& } \\
\text { Ghoreishi [28] }\end{array}$ \\
\hline
\end{tabular}


Table 1. Cont.

\begin{tabular}{|c|c|c|c|c|c|}
\hline Part & Separation Technique & Sample Preparation & Analysis Method & Determined Compounds * & Ref. \\
\hline & Subcritical extraction & $\begin{array}{l}\text { Ground samples of cinnamon were } \\
\text { extracted in n-butanol and ethanol. }\end{array}$ & $\begin{array}{l}\text { GC-MS (n-butanol extract) } \\
\text { HPLC-MS (ethanol extract) }\end{array}$ & $\begin{array}{l}\text { N-butanol extract-styrene, } \\
\text { benzaldehyde, camphene, } \beta \text {-pinene, } \\
\text { linalool, (Z)-cinnamaldehyde, } \\
\text { (E)-cinnamaldehyde (main) } \\
\alpha \text {-copaene, eugenol, coumarin, } \\
\text { methyl cinnamate } \\
\text { ethanol extract-procyanidin trimer, } \\
\text { catechin, coumarin, } \\
\text { (E)-cinnamaldehyde, } \\
\text { (Z)-cinnamaledehyde, } \\
\text { cinnamyl alcohol }\end{array}$ & Liang et al. [29] \\
\hline & Subcritical extraction & $\begin{array}{l}\text { Pulverized cinnamon was mixed with } \\
\text { distilled water. }\end{array}$ & HPLC & $\begin{array}{c}\text { Coumarin, cinnamic acid, } \\
\text { cinnamaldehyde, cinnamyl alcohol }\end{array}$ & Cha et al. [12] \\
\hline & Soxhlet extraction & $\begin{array}{l}\text { Cinnamon sticks were mashed into smaller } \\
\text { pieces and placed inside a thimble made } \\
\text { from thick filter paper. }\end{array}$ & HPLC & Cinnamaldehyde & Wong et al. [27] \\
\hline & Water extraction & $\begin{array}{c}\text { Crushed samples of cinnamon were } \\
\text { dissolved into distilled water after } \\
\text { lyophilization. }\end{array}$ & GC-MS & $\begin{array}{l}\text { Cinnamaldehyde, } 1,8 \text {-cineol, } \\
\alpha \text {-terpinolene, borneol, } \gamma \text {-terpinene, } \\
\text { benzaldehyde, carvacrol, } \delta \text {-3-carene }\end{array}$ & Jin \& Cho [30] \\
\hline & Water extraction & $\begin{array}{c}\text { Cinnamon dust was immerged in distilled } \\
\text { water and heated. }\end{array}$ & UPLC-MS/MS & $\begin{array}{l}\text { Quinic acid, shikimic acid, } \\
\text { L-tyrosine, nicotinamide, adenosine, } \\
\text { gallic acid, methyl-4-hydroxy-3- } \\
\text { methoxycinnamate, protocatechuic } \\
\text { acid, protocatechualdehyde, } \\
\text { perillene, (+)-catechin hydrate, } \\
\text { melittoside, abscisic acid, camphor, } \\
\text { coumarin, azelaic acid, } \\
\text { isopropyl-4-hydroxybenzoate, } \\
\text { 6-gingerol, citric acid, protocatechuic } \\
\text { acid, ferulaldehyde, } \\
\text { (+)-magnoflorine, curdione, rosavin, } \\
\text { abscisic acid, arglabin, } \\
\text { L(-)-carnitine }\end{array}$ & Tang et al. [16] \\
\hline
\end{tabular}


Table 1. Cont.

\begin{tabular}{|c|c|c|c|c|c|}
\hline Part & Separation Technique & Sample Preparation & Analysis Method & Determined Compounds * & Ref. \\
\hline & Sonohydrodistillation & $\begin{array}{l}\text { Extraction of essential oil from powdered } \\
\text { cinnamon was performed in a } \\
\text { sonohydrodistillation unit consisting of a } \\
\text { two-neck round-bottom flask. }\end{array}$ & GC-MS & Cinnamaldehyde & Modi et al. [31] \\
\hline & Ethanol extraction & $\begin{array}{l}\text { Plant cinnamon barks were powdered and } \\
\text { mixed with ethanol. }\end{array}$ & LC-MS/MS & $\begin{array}{c}\text { Caffeic acid, ferulic acid, pyrogallol, } \\
\text { p-hydroxybenzoic acid, vanillin, } \\
\text { p-coumaric acid, gallic acid, ascorbic } \\
\text { acid }\end{array}$ & Gulcin et al. [32] \\
\hline & Maceration extraction & $\begin{array}{l}\text { Liquid extracts were dried and diluted in } \\
\text { ethanol } 95 \% .\end{array}$ & $\begin{array}{l}\text { RP-HPLC, Folin-Ciocalteu } \\
\text { colorimetric method }\end{array}$ & Cinnamaldehyde, phenols & Othman et al. [13] \\
\hline & Solvent extraction & $\begin{array}{l}\text { Cinnamon powder was subjected to } \\
\text { different solvents (methanol, ethanol, } \\
\text { acetone, water). }\end{array}$ & UPLC-HRMS & $\begin{array}{c}\text { Protocatechuic acid, } \\
\text { 3,4-dihydroxybenzaldehyde } \\
\text { (protocatechualdehyde), catechin, } \\
\text { epicatechin, procyanidin B2, } \\
\text { cinnamic acid, quercitrin } \\
\text { (quercetin-3-rhamnoside), coumarin, } \\
\text { syringic acid, rutin }\end{array}$ & Muhammad et al. [33] \\
\hline & - & $\begin{array}{c}\text { Cinnamon powder was applied to the } \\
\text { capillary by dipping it in the powder. } \\
\text { The capillary was then placed in the } \\
\text { helium stream. }\end{array}$ & DART-MS & $\begin{array}{l}\text { Coumarin, cinnamaldehyde, } \\
\text { trans-cinnamaldehyde, } \\
\text { trans-cinnamic acid, eugenol, } \\
\text { benzaldehyde, estragole, linalool, } \\
\text { cinnamyl alcohol }\end{array}$ & Pavlovich et al. [35] \\
\hline
\end{tabular}

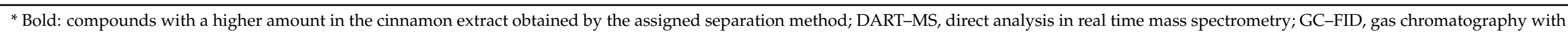

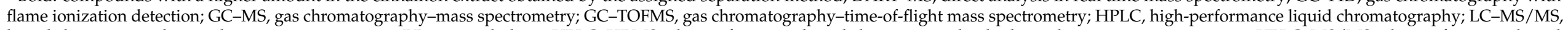

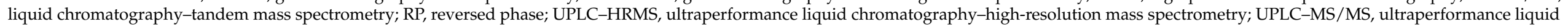
chromatography-tandem mass spectrometry. 


\subsection{Properties of Compounds Naturally Occurring in Cinnamon}

\subsubsection{Antioxidant Activity}

Antioxidant compounds are important in human life as health-protective agents. They are present in natural food, but they are also additives in the food industry used to prevent deterioration. One of the sources of antioxidant compounds is cinnamon. This simple spice can affect diseases. Ervina et al. [36] showed that cinnamon bark infusion has high antioxidant activities due to the presence of polyphenols and volatile oil compounds. Simple preparation of extract can be applied as a high antioxidant issue [36,37].

Cinnamon spice is a source of natural antioxidants that play a key role in the process of aging and diseases. Cinnamomum zeylanicum and Cinnamomum cassia (L.) J. Presl have the highest potential. Extract from the bark of this kind contains biologically active compounds such as eugenol, trans-cinnamaldehyde, and linalool. Phytonutrients have been investigated in the stabilization of palm oil. They prevent the generation of alcohols, ketone, aldehyde, acids, and hydrocarbons. The addition of antioxidants inhibits episodes of the oxidation process of oil, reducing the production of dangerous oxidative derivates and free fatty acids [38].

As mentioned, compounds contained in cinnamon can also be applied as healthprotective agents. Encapsulating cinnamon antioxidants increases their antioxidant efficacy. A diet enriched with these compounds brings benefits, contributing to a decrease in inflammation-triggering oxidative stress [39]. Antioxidants are regarded as factors of progress and are associated with human life due to their influence on metabolic diseases (e.g., glycemic diseases). However, the yield of potential extracts from cinnamon depends on the maturity of plants. Prabhashini et al. [40] confirmed that mature cinnamon leaves are most effective in managing oxidative stress related to chronic disease. The main compound supporting natural medicine is cinnamaldehyde and its analogues. However, two new compounds were investigated: lignan pinoresinol (PRO) and flavonol (-)-(2R,3R)5,7-dimethoxy-3', 4'-methylenedioxy-flavan-3-ol (MFO), which are also important in natural medicine as inhibitors of effects of oxidative stress [41]. According to the phenolic profile, the main compounds of water extracts of cinnamon are p-hydroxybenzoic acid, p-coumaric acid, caffeic acid, ferulic acid, vanillin, and gallic acid, but ethanol extracts additionally contain ascorbic acid. They are multifunctional biologically active compounds, reducing $\mathrm{Fe}^{3+}$ and $\mathrm{Cu}^{2+}$ and inhibiting some enzymes. Ethanol extracts were more effective against $\alpha$-glucosidase, butyrylcholinesterase (BChE), and $\alpha$-amylase as an inhibitor [32].

Cinnamon can be also used as preservatives in food products. (E)-Cinnamaldehyde is applied as a factor inhibiting the activation of tyrosinase as a suppressor of hyperpigmentation, the browning effect observed in fruits, vegetables, and mushrooms. Hence, cinnamon agents are related to a wide range of applications, such as in disease, the food industry, medicine, and the cosmetic industry [42].

Tannins, phenolic derivatives, are one of the groups of nonvolatile bioactive compounds determined in cinnamon. They have antioxidant properties and promising therapeutic potential for treating various diseases and metabolic disorders. Both classes of these compounds are present in cinnamon: condensed tannins (proanthocyanidins) and hydrolysable tannins [43]. Tannins exhibit beneficial pharmacological effects. Hydrolysis of tannins in a microbial setting results in the formation of bioavailable metabolites responsible for the beneficial systemic effects [44].

Tannin quantity is determined at the percentage level and depends on the species of cinnamon [45]. The tannin contents (expressed as catechin equivalent) of Cinnamomum zeylanicum and Cinnamomum cassia (L.) J. Presl were $2.18 \%$ and $0.65 \%$, respectively. In another study [46], LC-MS analysis showed that extract from Cinnamomum burmannii contained high levels of condensed tannins, proanthocyanidins (23.2\%), and (epi)catechins (3.6\%).

\subsubsection{Antidiabetic Activities}

Diabetes is a metabolic disorder that can cause many health complications. Diabetes mellitus type 2 is the most common. Traditional medicine is based on synthetic drugs, but 
herbal ones are becoming increasingly popular due to their bioactive properties. The main strategy is associated with the inhibition of $\alpha$-amylase and $\alpha$-glucosidase enzymes, which are related to the hydrolysis of carbohydrates in the digestive tract. In the water extract of Cinnamomum zeylanicum prepared using high pressure and the decoction method, benzoic acid, (E)-cinnamaldehyde, trans-cinnamic acid, eugenol, and o-methoxy-cinnamaldehyde were found. These bioactive compounds extracted by this method have huge potential to inhibit $\alpha$-glucosidase and control hyperglycemia [5]. Cinnamaldehyde is a predominant compound in the bark oil extracted from Cinnamomum zeylanicum. It seems to reduce plasma glucose levels more effectively than metformin, which is commonly used in traditional medicine. Bioactive compounds of cinnamon oil enhance the expression of proteins that play a key role during glucose transport, insulin signaling, and the regulation of dyslipidemia. Disturbances in the balance between free radicals and oxidative stress can also lead to tissue damage. Oxidative stress at a high level increases insulin resistance. This causes impairment of glucose tolerance and diabetes type 2 . This research confirmed that cinnamon consists of bioactive compounds that ensure this balance $[47,48]$.

\subsection{Cinnamon in the Treatment of Diseases and Disorders}

Cinnamon is well known in Western natural medicine as a natural species with healing properties. Nowadays, it is also reported as a plant with special attributes used to treat many disorders (Figure 2).

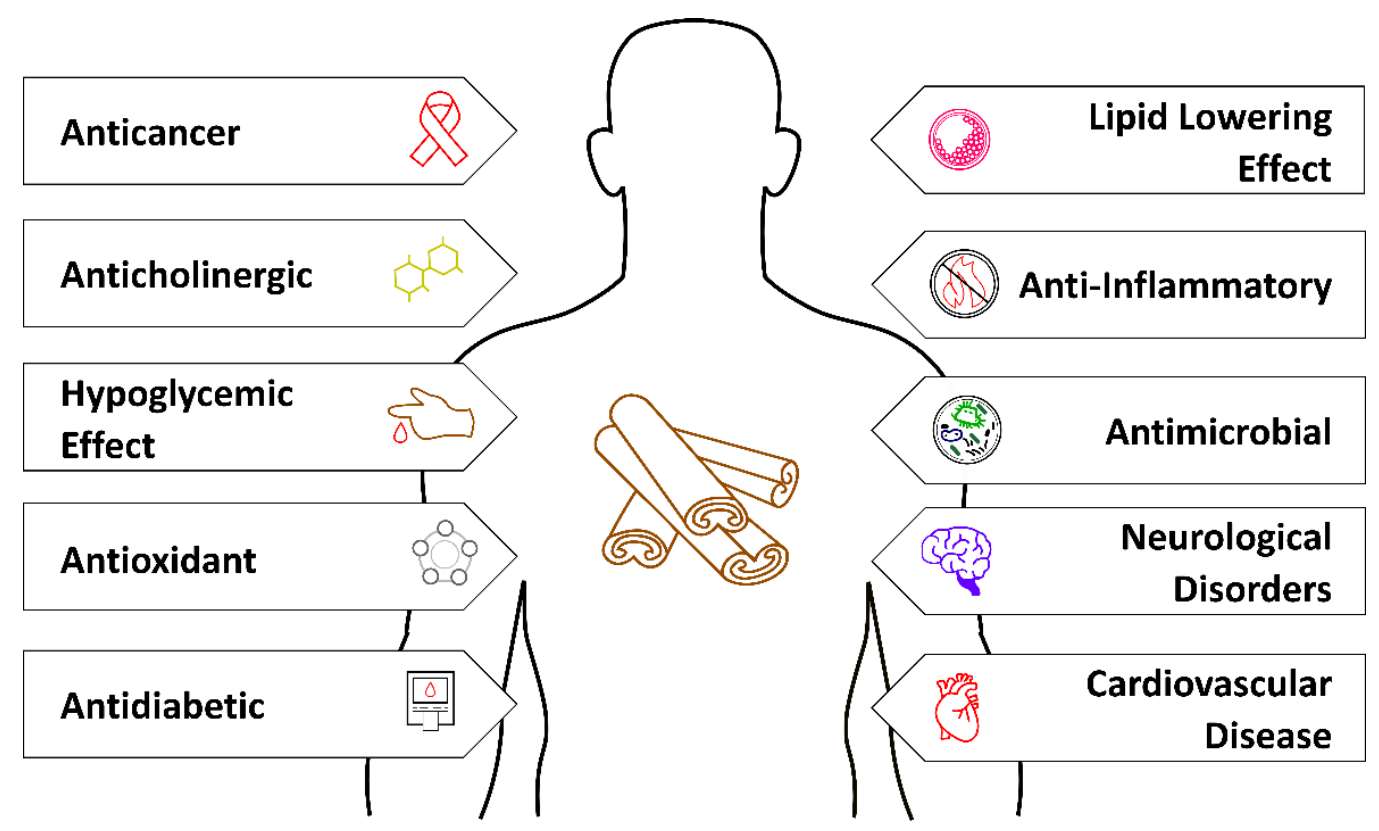

Figure 2. Cinnamon in the treatment of diseases and disorders $[4,8,12,13,17,37,46-55]$.

\subsubsection{Alzheimer's Disease}

Traumatic brain injury is a devastating disease that ranges from reversible neurochemical cascades to neuronal damage and behavioral impairment. Inflammation, injury, blood-brain barrier disruption, excitotoxicity, ionic homeostasis, and mitochondrial dysfunction play a critical role in the development of different neurological disorders. The majority of conservative medicinal therapies fail to limit the injury after traumatic brain injury (TBI) [49]. Most clinical research shows that early intervention and treatment are the only way to slow down or reverse the disease. Components of diet affect the incidence, severity, and management of many health issues, such as chronic diseases [50]. Alzheimer's disease $(\mathrm{AD})$ is caused by the degeneration of neuron-rich regions. Acetylcholine is correlated with memory function. Treatment of AD consists of the application of inhibitors of cholinesterase. However, they cannot modify the course of the disease. There are also other causes of $\mathrm{AD}$, such as the presence of senile plaques, which contain fibrils composed of 
amyloid beta peptide and hyperphosphorylated tau protein [51]. Oxidative stress can produce oligomers $A \beta$ through the activation of enzymes to reduce the production of amyloid $\beta$, which make the formation of amyloid plaque highly possible [52]. Polyphenolic derivatives present in the cinnamon extract are active against the alteration of oxidative stress enzymes. Cinnamomum zeylanicum was able to provide protection against Alzheimer's disease and dementia in scopolamine-induced memory impairment experimental rat models attributed to a certain reduction in the measurement of malondialdehyde (MDA) and glutathione oxidative stress parameters [53]. The activity of cinnamon aldehyde depends on the amount of its metabolites. This bioactive compound is well distributed through the body. Part of aldehyde is metabolized into hippuric acid in the liver and methyl cinnamate and cinnamyl alcohol in the plasma. The interaction of polyphenols with the blood barrier is a determining factor [8].

\subsubsection{Parkinson's Disease}

Parkinson's disease (PD) is one of the most common neurological disorders. PD patients display both motor and nonmotor symptoms. PD disease is related to neurodegeneration in the midbrain structure called black matter, and it leads to a decrease in the levels of dopamine in the brain. One of the conceptions regarding aging and the loss of essential black cells is connected to the decrease in dopamine in the organism. Additionally, oxidative stress and free radicals play a role. However, many factors indicate PD. In the pathomorphological image of PD, inside the neurons Lewy bodies are visible. They are built from $\alpha$-synuclein protein. PD patients are characterized by an abnormal conformation of this protein, which leads to the secondary accumulation of $\beta$-amyloid and consequently to death [54].

Research on the medicinal properties of cinnamon oil in PD suggests that the extract may have an effect on neurons and can delay the progression of several neurological disorders. Cinnamon can modulate several intracellular pathways and functions of mitochondria. Mutation of the DJ-1 gene is responsible for some autosomal recession and early-onset PD. It is connected to oxidative stress and mitochondrial dysfunction [55].

According to several studies, sodium benzoate (a component of cinnamon extract) can reverse the lipopolysaccharide-induced inhibition of the DJ-1 gene in neurons and exert neuroprotective effects. Compounds of cinnamon extract are responsible for the regulation of mitochondria and apoptosis functioning. Cinnamon compounds containing sodium benzoate are promising natural products against PD [56].

\subsubsection{Other Applications of Cinnamon}

To date, a number of studies have been carried out to check the bioactivity of cinnamon compounds against diseases. Cinnamon is rich in cinnamic acid, cinnamic aldehyde, cinnamyl acetate, $\alpha$-thujene, terpineol, $\alpha$-cubebene, eugenol, and coumarin. These compounds have strong antibacterial and anti-inflammatory properties and influence biological processes in the human body [57].

Scientific literature studies suggest that species of Cinnamomum are used in traditional medicine to treat a multitude of daily disorders, such as colds, indigestion, coughs, and microbial infections. Extracts from cinnamon released during ingestion have a positive effect on the treatment of diseases. Cinnamon is used as a medicine for stomachache, chest tightness, diarrhea, dyspepsia, and gastritis [58]. Cinnamon bark oil is used to treat indigestion, diabetes, acne, respiratory, and urinary disease. Cinnamon shows a therapeutic activity in benign prostatic hyperplasia. This is achieved by inhibiting the protein specific to the prostate [59].

The water extract of cinnamon leaves is used to treat alopecia. It significantly promotes the proliferation of human hair dermal papilla cells [50].

The bioactive properties of cinnamon compounds can affect the growth of Escherichia coli, which can cause common urinary infections [60]. The application of patches with 
cinnamon extract brings positive results in the treatment of overactive bladder syndrome and urinary incontinence [61].

Cinnamon is also one of the nutraceuticals. It is a natural food ingredient with pharmacological properties. Reports suggest that it can also support patients with cardiovascular diseases who suffer from hypertension. Clinical studies show that natural compounds, including cinnamon, support the process of reducing cardiovascular risk, preceded by modulation of other factors, such as oxidative stress, inflammation, hyperlipidemia, and vascular resistance [62]. Studies on a group of rats with seven healthy rats, seven rats with diabetes treated with probiotics, seven rats treated with cinnamon extract, and seven rats with a mixed form of treatment showed that the use of cinnamon extract added to the food reduced not only the level of blood glucose but also the level of cholesterol and triglycerides in the blood [63].

Cinnamon oil has also been found to be promising in the treatment of cancers, such as stomach cancer and melanoma. Cinnamaldehyde and eugenol show good results in the treatment of leukemia and lymphoma. These compounds have also been used as nutraceuticals in fighting colon and liver cancer cells [64].

Another interesting finding concerns the effect of cinnamon oil on hypothermia. The compounds present in the extract activate brown adipose tissue in the body. Body temperature and energy expenditure are increased by administering cinnamon extract in a cold environment. The number of mitochondria increases, and the expression of the thermogenic protein is increased. Moreover, administration of the extract alleviated damage to the heart muscle in a cold environment [65]. Cinnamon compounds are also applied for migraine prevention. This disease is associated with obesity. An increased body mass index is an important factor for migraine attacks. A total of 50 patients with migraines took part in a test that used treatment of this order. Half of them were the control group, and the other half received $600 \mathrm{mg}$ of cinnamon. The results revealed that the inclusion of cinnamon in the diet made it possible to control weight gain and, consequently, body mass index. Daily headaches significantly decreased in these patients. These findings showed that cinnamon could be complementary in treating migraine [66].

Cinnamon extract is also a promising natural substance that could be incorporated into oral products to control bad breath by inhibiting the growth of Solobacterium moorei, killing the biofilm, and reducing hydrogen sulfide $\left(\mathrm{H}_{2} \mathrm{~S}\right)$ production by Solobacterium moorei. Cinnamon oil in mouthwash is used as an antimicrobial agent, and it is an alternative to chlorhexidine. Concentration of cinnamon oil has no toxic effects on oral keratinocytes, so it can be used as a daily hygiene product. Natural extracts are a complex mixture of terpenoids, phenylpropanoids, and oxygenated derivatives (aldehydes, ketones, alcohols, and esters) $[67,68]$.

Presented in this review, the latest research findings clearly show that there is a link between the correct functioning of the human organism and nutrition, the quality of food and health, and biologically active components found in cinnamon. This information is particularly important in terms of reducing the risk of the occurrence and development of various diseases, including microcivilization diseases. In addition, the treatment of many diseases, such as diabetes, oxidative stress, and cardio disease, often requires the use of diet, which increases the effectiveness of pharmacological treatment and reduces the risk of complications. Knowledge of biologically active substances found in cinnamon can be a link between food and medicine and can prevent diseases that are exacerbated by the course of diseases aggravated by incorrect nutrition. Moreover, knowledge of the biologically active components in cinnamon can contribute to the preparation of individualized diets based on dishes with its addition. This article also brings elements of novelty to nutrition education based on compounds contained in cinnamon, which can be used in the production of pharmaceutical preparations or dietary supplements. It also shows the correlation between consumed food products, nutrients, and human health. 


\section{Conclusions}

Numerous studies have shown the presence of biologically active compounds in cinnamon, mainly cinnamaldehyde. Those compounds are found in different ratios in all plant parts and can be identified with the help of separation techniques. The bioactive compounds that are found in cinnamon can affect the human body in many different ways and can be applied to treat a wide range of diseases and metabolic disorders (Table 2). There is sufficient evidence that cinnamon can be used as a spice in daily life with a positive impact on human health. It has antimicrobial, antidiabetic, hepatoprotective, neuroprotective, cardioprotective, immunomodulatory, and anticancer usages. Due to its antioxidant and antimicrobial activities, it can be used as a killing agent for microbes. The anti-inflammatory and antidiabetic properties of these compounds indirectly affect the receptor-mediated mechanism. Recent studies have also shown the possibility of its application in COVID-19 symptom reduction and in preventive treatment through immune system strengthening.

This review proves that an everyday, inconspicuous spice can bring many health benefits to people and recommends the inclusion of cinnamon in daily diet. However, further research should focus on the development of an appropriate form and route of administration of cinnamon so that therapeutic effects are maximized.

Table 2. Examples of potential application of cinnamon in human health.

\begin{tabular}{|c|c|c|}
\hline Potential Effect & Description & Ref. \\
\hline Autoimmune disorders & $\begin{array}{l}\text { Cinnamon and its metabolite sodium benzoate }(\mathrm{NaB}) \\
\text { upregulate anti-autoimmune Tregs and Th2, suppress } \\
\text { autoimmune Th17 and Th1, inhibit inflammatory infiltration, } \\
\text { and reduce the expression of proinflammatory molecules. }\end{array}$ & Pahan \& Pahan [69] \\
\hline Antidiabetic & Cinnamon extract lowers blood glucose and cholesterol levels. & Sivaranjani et al. [70] \\
\hline Neuroprotective & $\begin{array}{l}\text { Results of research suggest that cotreatment of rats with } \\
\text { cinnamon oil alleviated the adverse effects of deltamethrin } \\
\text { pesticide in rats. Increased antioxidant defense system, } \\
\text { decreased stress levels, and regulation of gene expression may } \\
\text { be potential mechanisms underlying the ability of cinnamon oil } \\
\text { to prevent the neurotoxic effects of deltamethrin. }\end{array}$ & Ahmed et al. [71] \\
\hline Anticancer & $\begin{array}{c}\text { Cinnamaldehyde and cinnamon essential oil exhibit } \\
\text { antimicrobial properties and may be used in the prevention and } \\
\text { treatment of infections caused by Escherichia coli and in patients } \\
\text { with suspected colon cancer. }\end{array}$ & $\begin{array}{l}\text { Kosari et al. [72]; } \\
\text { Kumar et al. [73] }\end{array}$ \\
\hline Lipid lowering & $\begin{array}{l}\text { Cinnamon extract exhibits hypolipidemic activity in } \\
\text { hypercholesterolemic albino rats. Daily administration of the } \\
\text { extract reduced serum levels of total cholesterol, triglycerides, } \\
\text { and low-density lipoprotein cholesterol (LDL-C). }\end{array}$ & Kostner et al. [74] \\
\hline Antioxidant and antimicrobial & $\begin{array}{l}\text { Herbs including, but not limited to, cinnamon have } \\
\text { antibacterial, antiviral, and antioxidant properties with double } \\
\text { the effectiveness of synthetic supplements. }\end{array}$ & Parham et al. [75] \\
\hline COVID-19 treatment & $\begin{array}{l}\text { Cinnamon extract has the potential to limit overshooting } \\
\text { immune reactions in COVID-19. }\end{array}$ & Lucas et al. [76] \\
\hline $\mathrm{TiO}_{2} \mathrm{NPs}$ protector & $\begin{array}{c}\text { Cinnamon oil is a promising substance for the protection } \\
\text { against the hazards of } \mathrm{TiO}_{2} \mathrm{NPs} \text {. }\end{array}$ & Salman et al. [77] \\
\hline
\end{tabular}

Author Contributions: Conceptualization, J.K.-C. and N.B.; investigation, N.B.; writing-original draft preparation, N.B. and A.R.; writing-review and editing, J.K.-C. and A.R. All authors have read and agreed to the published version of the manuscript.

Funding: This research received no external funding.

Data Availability Statement: Not applicable. 
Acknowledgments: This review was completed while the first author was a doctoral candidate in the Interdisciplinary Doctoral School at Lodz University of Technology, Poland.

Conflicts of Interest: The authors declare no conflict of interest.

$\begin{array}{ll}\text { Abbreviations } & \\ \text { AD } & \text { Alzheimer's disease } \\ \text { BChE } & \text { butyrylcholinesterase } \\ \text { DART-MS } & \text { direct analysis in real time mass spectrometry } \\ \text { FTIR } & \text { Fourier-transform infrared spectroscopy } \\ \text { GC } & \text { gas chromatography } \\ \text { GCxGC-TOFMS } & \text { gas chromatography-time-of-flight mass spectrometry } \\ \text { GC-FID } & \text { gas chromatography coupled with flame ionization detection } \\ \text { GC-MS } & \text { gas chromatography-mass spectrometry } \\ \text { HPLC } & \text { high-performance liquid chromatography } \\ \text { IL } & \text { interleukin } \\ \text { LC-MS } & \text { liquid chromatography-mass spectrometry } \\ \text { LC-MS/MS } & \text { liquid chromatography-tandem mass spectrometry } \\ \text { LDL-C } & \text { low-density lipoprotein cholesterol } \\ \text { LPS } & \text { lipopolysaccharide } \\ \text { MDA } & \text { malondialdehyde } \\ \text { MFO } & \text { flavonol (-)-(2R,3R)-5,7-dimethoxy-3',4'-methylenedioxy-flavan-3-ol } \\ \text { NO } & \text { nitric oxide } \\ \text { PD } & \text { Parkinson's disease } \\ \text { PRO } & \text { lignan pinoresinol } \\ \text { SEM } & \text { scanning electron microscopy } \\ \text { TBI } & \text { traumatic brain injury } \\ \text { TNF } & \text { tumor necrosis factor } \\ \text { UPLC-HRMS } & \text { ultraperformance liquid chromatography-high-resolution mass spectrometry } \\ \text { UPLC-MS/MS } & \text { ultraperformance liquid chromatography-tandem mass spectrometry } \\ & \end{array}$

\section{References}

1. Rao, P.V.; Gan, S.H. Cinnamon: A multifaceted medicinal plant. Evid. Based Complementary Altern. Med. 2014, $2014,642942$. [CrossRef]

2. Abd El-Hack, M.E.; Alagawany, M.; Abdel-Moneim, A.M.E.; Mohammed, N.G.; Khafaga, A.F.; Bin-Jumah, M.; Othman, S.I.; Allam, A.A.; Elnesr, S.S. Cinnamon (Cinnamomum zeylanicum) oil as a potential alternative to antibiotics in poultry. Antibiotics 2020, 9, 210. [CrossRef] [PubMed]

3. Mohammadi, M.; Mirabzadeh, S.; Shahvalizadeh, R.; Hamishehkar, H. Development of novel active packaging films based on whey protein isolate incorporated with chitosan nanofiber and nano-formulated cinnamon oil. Int. J. Biol. Macromol. 2020, 149, 11-20. [CrossRef]

4. Gruenwald, J.; Freder, J.; Armbruester, N. Cinnamon and health. Crit. Rev. Food Sci. Nutr. 2010, 50, 822-834. [CrossRef] [PubMed]

5. Wariyapperuma, W.A.N.M.; Kannangara, S.; Yasanandana, S. In vitro anti-diabetic effects and phytochemical profiling of novel varieties of Cinnamomum zeylanicum (L.) extracts. Biochem. Biophys. Mol. Biol. 2020, 8, 1-23. [CrossRef] [PubMed]

6. Hariri, M.; Ghiasvand, R. Cinnamon and chronic diseases. Drug Discov. Mother Nat. Adv. Exp. Med. Biol. 2016, 929, 1-24. [CrossRef]

7. Mohammad, S.; Gharibzahedi, T. The preparation, stability, functionality and food enrichment ability of cinnamon oil-loaded nanoemulsion-based delivery systems: A review. Int. J. Nutraceuticals Funct. Foods Nov. Foods Res. Ind. Appl. 2018, 17, 97-105. [CrossRef]

8. Momtaz, S.; Hassani, S.; Khan, F.; Ziaee, M.; Abdollahi, M. Cinnamon, a promising prospect towards Alzheimer's disease. Pharmacol. Res. 2018, 130, 241-258. [CrossRef]

9. Dorri, M.; Hashemitabar, S.; Hosseinzadeh, H. Cinnamon (Cinnamomum zeylanicum) as an antidote or a protective agent against natural or chemical toxicities: A review. Drug Chem. Toxicol. 2018, 41, 338-351. [CrossRef]

10. Khasanah, L.U.; Prasetyawan, P.; Utami, R.; Atmaka, W.; Manuhara, G.J.; Sanjaya, A.P. Optimization and Characterization of Cinnamon Leaves (Cinnamomum burmannii) Oleoresin. IOP Conf. Ser. Mater. Sci. Eng. 2017, 193. [CrossRef]

11. Adarsh, A.; Chettiyar, B.; Kanthesh, B.M.; Raghu, N. Phytochemical Screening and Antimicrobial Activity of "Cinnamon zeylanicum". Int. J. Pharm. Res. Innov. 2020, 13, 22-33.

12. Cha, J.; Kim, C.T.; Kim, T.E.; Cho, Y.J. Optimization of subcritical extraction process for cinnamon (Cinnamomum Cassia Blume) using response surface methodology. Food Sci. Biotechnol. 2019, 28, 1703-1711. [CrossRef] [PubMed] 
13. Othman, Z.S.; Maskat, M.Y.; Hassan, N.H. Optimization of cinnamaldehyde extraction and antioxidant activity of ceylon cinnamon extract. Sains Malays. 2020, 49, 995-1002. [CrossRef]

14. Chen, G.; Sun, F.; Wang, S.; Wang, W.; Dong, J.; Gao, F. Enhanced extraction of essential oil from Cinnamomum cassia bark by ultrasound assisted hydrodistillation. Chin. J. Chem. Eng. 2020. [CrossRef]

15. Li, J.; Guan, E.; Chen, L.; Zhang, X.; Yin, L.; Dong, L.; Pan, Q.; Fu, X.; Zhang, L. Optimization for extraction of an oil recipe consisting of white pepper, long pepper, cinnamon, saffron, and myrrh by supercritical carbon dioxide and the protective effects against oxygen-glucose deprivation in PC12 cells. Rev. Bras. De Farmacogn. 2018, 28, 312-319. [CrossRef]

16. Tang, P.L.; Chen, Y.T.; Qin, J.; Hou, X.; Deng, J. Effect of cinnamon bark and twig extracts on the chemical, physicochemical and antioxidant properties of fermented milk. J. Food Meas. Charact. 2020, 14, 2271-2281. [CrossRef]

17. Da Silva, M.L.T.; Bernardo, M.A.S.; Singh, J.; de Mesquita, M.F. Beneficial uses of cinnamon in health and diseases: An interdisciplinary approach. In The Role of Functional Food Security in Global Health; Watson, R., Singh, R., Takahashi, T., Eds.; Academic Press: Cambridge, MA, USA, 2019; pp. 565-576.

18. Silva, F.L.; Silva, R.V.S.; Branco, P.C.; Costa-Lotufo, L.V.; Murakami, C.; Young, M.C.M.; Azevedo, D.A.; Moreno, P.R.H. Chemical composition of the Brazilian native Cinnamomum stenophyllum (Meisn.) Vattimo-Gil essential oil by GC-qMS and GCxGCTOFMS, and its cytotoxic activity. Arab. J. Chem. 2020, 13, 4926-4935. [CrossRef]

19. Farias, A.P.P.; Monteiro, O.D.S.; da Silva, J.K.R.; Figueiredo, P.L.B.; Rodrigues, A.A.C.; Monteiro, I.N.; Maia, J.G.S. Chemical composition and biological activities of two chemotype-oils from Cinnamomum verum J. Presl growing in North Brazil. J. Food Sci. Technol. 2020, 57, 3176-3183. [CrossRef] [PubMed]

20. Pragadheesh, V.S.; Saroj, A.; Yadav, A.; Chanotiya, C.S.; Alam, M.; Samad, A. Chemical characterization and antifungal activity of cinnamomum camphora essential oil. Ind. Crop. Prod. 2013, 49, 628-633. [CrossRef]

21. Jayaprakasha, G.K.; Rao, L.J.M. Chemistry, Biogenesis and Biological Activities of Cinnamomum zeylanicum. Crit. Rev. Food Sci. Nutr. 2011, 51, 547-562. [CrossRef]

22. Kaul, P.N.; Bhattacharya, A.K.; Rao, B.R.R.; Syamasundar, K.V.; Ramesh, S. Volatile constituents of essential oils isolated from different parts of cinnamon (Cinnamomum zeylanicum Blume). J. Sci. Food Agric. 2003, 55, 53-55. [CrossRef]

23. Abdelwahab, S.I.; Mariod, A.A.; Taha, M.M.E.; Zaman, F.Q.; Abdelmageed, A.H.A.; Khamis, S.; Sivasothy, Y.; Awang, K. Chemical composition and antioxidant properties of the essential oil of Cinnamomum altissimum Kosterm. (Lauraceae). Arab. J. Chem. 2017, 10, 131-135. [CrossRef]

24. Kallel, I.; Hadrich, B.; Gargouri, B.; Chaabane, A.; Lassoued, S.; Gdoura, R.; Bayoudh, A.; Ben Messaoud, E. Optimization of Cinnamon (Cinnamomum zeylanicum Blume) Essential Oil Extraction: Evaluation of Antioxidant and Antiproliferative Effects. Evid. Based Complementary Altern. Med. 2019, 9, 1-11. [CrossRef] [PubMed]

25. Muhammad, D.R.A.; Lemarcq, V.; Alderweireldt, E.; Vanoverberghe, P.; Praseptiangga, D.; Juvinal, J.G.; Dewettinck, K. Antioxidant activity and quality attributes of white chocolate incorporated with Cinnamomum burmannii Blume essential oil. J. Food Sci. Technol. 2020, 57, 1731-1739. [CrossRef]

26. Gotmare, B.; Tambe, E. Identification of Chemical Constituents of Cinnamon Bark Oil by GCMS and Comparative Study Garnered from Five Different Countries. Glob. J. Sci. Front. Res. Biol. Sci. 2019, 19, 35-42.

27. Wong, Y.C.; Ahmad-Mudzaqqir, M.Y.; Wan-Nurdiyana, W.A. Extraction of essential oil from cinnamon (Cinnamomum zeylanicum). Orient. J. Chem. 2014, 30, 37-47. [CrossRef]

28. Masghati, S.; Ghoreishi, S.M. Supercritical $\mathrm{CO}_{2}$ extraction of cinnamaldehyde and eugenol from cinnamon bark: Optimization of operating conditions via response surface methodology. J. Supercrit. Fluids 2018, 140, 62-71. [CrossRef]

29. Liang, Y.; Li, Y.; Sun, A.; Liu, X. Chemical compound identification and antibacterial activity evaluation of cinnamon extracts obtained by subcritical n-butane and ethanol extraction. Food Sci. Nutr. 2019, 7, 2186-2193. [CrossRef]

30. Jin, S.; Cho, K.H. Water extracts of cinnamon and clove exhibits potent inhibition of protein glycation and anti-atherosclerotic activity in vitro and in vivo hypolipidemic activity in zebrafish. Food Chem. Toxicol. 2011, 49, 1521-1529. [CrossRef]

31. Modi, P.I.; Parikh, J.K.; Desai, M.A. Industrial Crops \& Products Sonohydrodistillation: Innovative approach for isolation of essential oil from the bark of cinnamon. Ind. Crop. Prod. 2019, 142, 111838. [CrossRef]

32. Gulcin, I.; Kaya, R.; Goren, A.C.; Akincioglu, H.; Topal, M.; Bingol, Z.; Çakmak, K.C.; Sarikaya, S.B.O.; Alwasel, S. Anticholinergic, antidiabetic and antioxidant activities of cinnamon (cinnamomum verum) bark extracts: Polyphenol contents analysis by LCMS/MS. Int. J. Food Prop. 2019, 22, 1511-1526. [CrossRef]

33. Muhammad, D.R.A.; Tuenter, E.; Patria, G.D.; Foubert, K.; Pieters, L.; Dewettinck, K. Phytochemical composition and antioxidant activity of Cinnamomum burmannii Blume extracts and their potential application in white chocolate. Food Chem. 2021, 340, 127983. [CrossRef] [PubMed]

34. Pashazadeh, B.; Elhamirad, A.H.; Hajnajari, H.; Sharayei, P.; Armin, M. Optimization of the pulsed electric field -assisted extraction of functional compounds from cinnamon. Biocatal. Agric. Biotechnol. 2020, 23, 101461. [CrossRef]

35. Pavlovich, M.J.; Musselman, B.; Hall, A.B. Direct, Real-Time Mass Spectrometry Analysis of Cinnamon. American Laboratory 2016. Available online: https:/ / www.americanlaboratory.com/914-Application-Notes /185014-Direct-Real-Time-Mass-SpectrometryAnalysis-of-Cinnamon/ (accessed on 31 March 2021).

36. Ervina, M.; Nawu, Y.E.; Esar, S.Y. Comparison of in vitro antioxidant activity of infusion, extract and fractions of Indonesian Cinnamon (Cinnamomum burmannii) bark. Int. Food Res. J. 2016, 23, 1346-1350. 
37. Yashin, A.; Yashin, Y.; Xia, X.; Nemzer, B. Antioxidant Activity of Spices and Their Impact on Human Health: A Review. Antioxidants 2017, 6, 70. [CrossRef]

38. Shahid, M.Z.; Saima, H.; Yasmin, A.; Nadeem, M.T.; Imran, M.; Afzaal, M. Antioxidant capacity of cinnamon extract for palm oil stability. Lipids Health Dis. 2018, 1, 1-8. [CrossRef]

39. Pisoschi, A.M.; Pop, A.; Iordache, F.; Stanca, L.; Predoi, G.; Serban, A.I. Oxidative stress mitigation by antioxidants-An overview on their chemistry and influences on health status. Eur. J. Med. Chem. 2021, 209, 112891. [CrossRef]

40. Prabhashini, W.; Mendis, K.; Premakumara, S.; Arachchige, G.; Kanchana, W.; Mendis, S.; Ratnasooriya, W.D.; Medawattegedara, H.; Indeewari, U. Antioxidant and Glycemic Regulatory Properties Potential of Different Maturity Stages of Leaf of Ceylon Cinnamon (Cinnamomum zeylanicum Blume) In vitro. Evid. Based Complementary Altern. Med. 2019, 2019. [CrossRef]

41. Li, A.L.; Li, G.H.; Li, Y.R.; Wu, X.Y.; Ren, D.M.; Lou, H.X.; Wang, X.N.; Shen, T. Lignan and flavonoid support the prevention of cinnamon against oxidative stress related diseases. Phytomedicine 2019, 53, 143-153. [CrossRef]

42. Georgiev, L.; Chochkova, M.; Totseva, I.; Seizova, K.; Marinova, E.; Ivanova, G.; Ninova, M.; Najdenski, H.; Milkova, T. Anti-tyrosinase, antioxidant and antimicrobial activities of hydroxycinnamoylamides. Med. Chem. Res. 2013, 22, 4173-4182. [CrossRef]

43. Ghosh, D. Tannins from Foods to Combat Diseases. Int. J. Pharma Res. Rev. 2015, 4, 40-44.

44. Sallam, E. Effect of Gut Microbiota Biotransformation on Dietary Tannins and Human Health Implications. Microorganism 2021, 9, 965. [CrossRef]

45. Al-Numair, K.S.; Ahmad, D.; Ahmed, S.B.; Al-Assaf, A.H. Nutritive value, levels of polyphenols and anti-nutritional factors in Sri Lankan cinnamon (Cinnamomum Zeyalnicum) and Chinese Cinnamon (Cinnamomum Cassia). Food Sci. Agric. Res. Center King Saud Univ. 2007, 154, 5-21.

46. Shan, B.; Cai, Y.Z.; Brooks, D.J.; Corke, H. Antibacterial Properties and Major Bioactive Components of Cinnamon Stick (Cinnamomum burmannii): Activity against Foodborne Pathogenic Bacteria. J. Agric. Food 2007, 55, 5484-5490. [CrossRef] [PubMed]

47. Sharma, S.; Mandal, A.; Kant, R.; Jachak, S.; Jagzape, M. Is Cinnamon Efficacious for Glycaemic Control in Type-2 Diabetes Mellitus? J. Pak. Med Assoc. 2020, 70, 2065-2069.

48. Tangvarasittichai, S. Oxidative stress, insulin resistance, dyslipidemia and type 2 diabetes mellitus. World J. Diabetes 2015, 6, 456-480. [CrossRef]

49. Yulug, B.; Kilic, E.; Altunay, S.; Ersavas, C.; Orhan, C.; Dalay, A.; Tuzcu, M.; Sahin, N.; Juturu, V.; Sahin, K. Cinnamon Polyphenol Extract Exerts Neuroprotective Activity in Traumatic Brain Injury in Male Mice. CNS Neurol. Disord. Drug Targets 2018, 17, 439-447. [CrossRef]

50. Ibrahim, J.E.; Anderson, L.J.; Macphail, A.; Lovell, J.J.; Davis, M.; Winbolt, M. Chronic disease self-management support for persons with dementia, in a clinical setting. J. Multidiscip. Healthc. 2017, 10, 49-58. [CrossRef]

51. Huang, L.; Chao, S.; Hu, C. Clinical trials of new drugs for Alzheimer disease. J. Biomed. Sci. 2020, 7, 1-13. [CrossRef]

52. Devi, L.; Alldred, M.J.; Ginsberg, S.D.; Ohno, M. Mechanisms Underlying Insulin Deficiency-Induced Acceleration of bAmyloidosis in a Mouse Model of Alzheimer's Disease. PLoS ONE 2012, 7, e32792. [CrossRef]

53. Jain, S.; Sangma, T.; Shukla, S.K.; Mediratta, P.K. Effect of Cinnamomum zeylanicum extract on scopolamine-induced cognitive impairment and oxidative stress in rats. Nutr. Neurosci. 2014, 18, 210-216. [CrossRef]

54. Tan, E.K.; Chao, Y.X.; West, A.; Chan, L.L.; Poewe, W.; Jankovic, J. Parkinson disease and the immune system-Associations, mechanisms and therapeutics. Nat. Rev. Neurol. 2020, 16, 303-318. [CrossRef] [PubMed]

55. Dolgacheva, L.P.; Berezhnov, A.V.; Fedotova, E.I.; Zinchenko, V.P.; Abramov, A.Y. Role of DJ-1 in the mechanism of pathogenesis of Parkinson's disease. J. Bioenerg. Biomembr. 2019, 51, 175-188. [CrossRef] [PubMed]

56. Angelopoulou, E.; Paudel, Y.N.; Piperi, C.; Mishra, A. Neuroprotective potential of cinnamon and its metabolites in Parkinson's disease: Mechanistic insights, limitations, and novel therapeutic opportunities. J. Biochem. Mol. Toxicol. 2021. [CrossRef]

57. Mohamed, A.E.; Abdur, R.; Sadeek Alaa, M.M. Cinnamon bark as antibacterial agent: A mini-review. GSC Biol. Pharm. Sci. 2020, 10, 103-108. [CrossRef]

58. Wang, J.; Su, B.; Jiang, H.; Cui, N.; Yu, Z.; Yang, Y.; Sun, Y. Traditional uses, phytochemistry and pharmacological activities of the genus Cinnamomum (Lauraceae): A review. J. Pre Proof Fitoter. 2020, 104675. [CrossRef] [PubMed]

59. Husain, I.; Ahmad, R.; Chandra, A.; Raza, S.T.; Shukla, Y.; Mahdi, F. Phytochemical characterization and biological activity evaluation of ethanolic extract of Cinnamomum zeylanicum. J. Ethnopharmacol. 2018, 219, 110-116. [CrossRef]

60. Harini, S.; Suneetha, V. Disinfectant for Urinary Infection Caused by Escherichia coli by Using Natural Oils. J. Biosci. Med. 2020, 8, 96-103. [CrossRef]

61. Chen, L.L.; Shen, Y.C.; Ke, C.C.; Imtiyaz, Z.; Chen, H.I.; Chang, C.H.; Lee, M.H. Efficacy of cinnamon patch treatment for alleviating symptoms of overactive bladder: A double-blind, randomized, placebo-controlled trial. Phytomedicine 2021, 80, 153380. [CrossRef]

62. Ghaffari, S.; Roshanravan, N. The role of nutraceuticals in prevention and treatment of hypertension: An updated review of the literature. Food Res. Int. 2020, 128. [CrossRef]

63. Shahrestan, F.; Jafari, P.; Gharebaghi, A.; Khani Farahani, I.; Shahrestan, E. Effect of Bioflora and Cinnamon Extract Consumption on Dyslipidemia and Cardiovascular Disease in a Diabetic Rat Model. J. Arak Univ. Med Sci. 2020, 23, 198-209. [CrossRef]

64. Goel, B.; Mishra, S. Medicinal and Nutritional Perspective of Cinnamon: A Mini-review. Eur. J. Med. Plants 2020, 31, 10-16. [CrossRef] 
65. Li, X.; Lu, H.Y.; Jiang, X.W.; Yang, Y.; Xing, B.; Yao, D.; Wu, Q.; Xu, Z.H.; Zhao, Q.C. Cinnamomum cassia extract promotes thermogenesis during exposure to cold via activation of brown adipose tissue. J. Ethnopharmacol. 2021, 266, 113413. [CrossRef]

66. Zareie, A.; Bagherniya, M.; Sharma, M.; Khorvash, F.; Hasanzadeh, A.; Askari, G. Effects of Cinnamon on Anthropometry Status and Headache Disability of Migraine Patients: A Randomized Double-blind Placebo-controlled Trial. J. Headache Pain 2020. [CrossRef]

67. Mutans, S. Evaluation of the Antibacterial Effect of Cinnamon Extract on Streptococcus Mutans. Al-Azhar Dent. J. Girls 2021, 8, 123-128. [CrossRef]

68. LeBel, G.; Haas, B.; Adam, A.A.; Veilleux, M.P.; Lagha, A.B.; Grenier, D. Effect of cinnamon (Cinnamomum verum) bark essential oil on the halitosis-associated bacterium Solobacterium moorei and in vitro cytotoxicity. Arch. Oral Biol. 2017, 83, 97-104. [CrossRef]

69. Pahan, S.; Pahan, K. Can cinnamon spice down autoimmune diseases? J. Clin. Exp. Immunol. 2020, 5, 252-258. [CrossRef]

70. Sivaranjani, R.; Zachariah, T.J.; Leela, N.K. Phytotherapeutic potential of bi-herbal extract of cinnamon and turmeric: In vivo antidiabetic studies. Clin. Phytoscience 2021, 7, 1-9. [CrossRef]

71. Ahmed, W.M.S.; Abdel-Azeem, N.M.; Ibrahim, M.A.; Helmy, N.A.; Radi, A.M. Neuromodulatory effect of cinnamon oil on behavioural disturbance, CYP1A1, iNOStranscripts and neurochemical alterations induced by deltamethrin in rat brain. Ecotoxicol. Environ. Saf. 2021, 209, 111820. [CrossRef]

72. Kosari, F.; Taheri, M.; Moradi, A.; Alni, R.H.; Alikhani, M.Y. Evaluation of cinnamon extract effects on clbB gene expression and biofilm formation in Escherichia coli strains isolated from colon cancer patients. BMC Cancer 2020, 20, 1-8. [CrossRef]

73. Kumar, S.; Kumari, R.; Mishra, S. Pharmacological properties and their medicinal uses of Cinnamomum: A review. J. Pharm. Pharmacol. 2019, 17, 735-1761. [CrossRef] [PubMed]

74. Kostner, G.M.; Alsoodeeri, F.N.; Alqabbani, H.M.; Aldossari, N.M. Effects of Cinnamon (Cinnamomum cassia) Consumption on Serum Lipid Profiles in Albino Rats. J. Lipids 2020, 2020, 1-7. [CrossRef]

75. Parham, S.; Kharazi, A.Z.; Bakhsheshi-Rad, H.R.; Nur, H.; Ismail, A.F.; Sharif, S.; RamaKrishna, S.; Berto, F. Antioxidant, Antimicrobial and Antiviral Properties of Herbal Materials. Antioxidants 2020, 9, 1309. [CrossRef]

76. Lucas, K.; Fröhlich-Nowoisky, J.; Oppitz, N.; Ackermann, M. Cinnamon and Hop Extracts as Potential Immunomodulators for Severe COVID-19 Cases. Front. Plant Sci. 2021, 12, 1-7. [CrossRef] [PubMed]

77. Salman, A.S.; Al-Shaikh, T.M.; Hamza, Z.K.; El-Nekeety, A.A.; Bawazir, S.S.; Hassan, N.S.; Abdel-Wahhab, M.A. Matlodextrincinnamon essential oil nanoformulation as a potent protective against titanium nanoparticles-induced oxidativestress, genotoxicity, and reproductive disturbances in male mice. Environ. Sci. Pollut. Res. 2021. [CrossRef] [PubMed] 